\title{
Article \\ Gas Plasma Exposure of Glioblastoma Is Cytotoxic and Immunomodulatory in Patient-Derived GBM Tissue
}

\author{
Sander Bekeschus ${ }^{1, *}++^{\mathbb{D}}$, Mikael Ispirjan ${ }^{1,2,+}$, Eric Freund ${ }^{1,3, \ddagger(\mathbb{D})}$, Frederik Kinnen ${ }^{1,2, \ddagger}$, Juliane Moritz $^{1, \ddagger}$, \\ Fariba Saadati ${ }^{1,4}$, Jacqueline Eckroth ${ }^{1}$, Debora Singer ${ }^{1}{ }^{\mathbb{D}}$, Matthias B. Stope ${ }^{5}$, Kristian Wende ${ }^{1} \mathbb{D}$, \\ Christoph A. Ritter ${ }^{6}$, Henry W. S. Schroeder ${ }^{2}$ and Sascha Marx ${ }^{2,7}$
}

1 ZIK plasmatis, Leibniz Institute for Plasma Science and Technology (INP), Felix-Hausdorff-Str. 2, 17489 Greifswald, Germany; mikael.ispirjan@stud.uni-greifswald.de (M.I.); eric.freund@inp-greifswald.de (E.F.); fk133993@uni-greifswald.de (F.K.); juliane.moritz@inp-greifswald.de (J.M.); fariba.saadati@inp-greifswald.de (F.S.); jacqueline.eckroth@inp-greifswald.de (J.E.); debora.singer@inp-greifswald.de (D.S.); kristian.wende@inp-greifswald.de (K.W.)

2 Department of Neurosurgery, Greifswald University Medical Center, Ferdinand-Sauerbruch-Str., 17475 Greifswald, Germany; henry.schroeder@uni-greifswald.de (H.W.S.S.); sascha.marx@uni-greifswald.de (S.M.)

3 Department of General, Visceral, Thoracic, and Vascular Surgery, Greifswald University Medical Center, Ferdinand-Sauerbruch-Str., 17475 Greifswald, Germany

4 Clinic and Policlinic for Dermatology and Venerology, Rostock University Medical Center, Strempelstr. 13, 18057 Rostock, Germany

5 Department of Gynecology and Gynecological Oncology, Bonn University Medical Center, Venusberg-Campus 1, 53127 Bonn, Germany; matthias.Stope@ukbonn.de

check for updates

Citation: Bekeschus, S.; Ispirjan, M.; Freund, E.; Kinnen, F.; Moritz, J.; Saadati, F.; Eckroth, J.; Singer, D.; Stope, M.B.; Wende, K.; et al. Gas Plasma Exposure of Glioblastoma Is Cytotoxic and Immunomodulatory in Patient-Derived GBM Tissue. Cancers 2022, 14, 813. https://doi.org/ 10.3390/cancers 14030813

Academic Editor: Ahmed Hassanein

Received: 22 December 2021

Accepted: 3 February 2022

Published: 5 February 2022

Publisher's Note: MDPI stays neutral with regard to jurisdictional claims in published maps and institutional affiliations.

Copyright: () 2022 by the authors. Licensee MDPI, Basel, Switzerland. This article is an open access article distributed under the terms and conditions of the Creative Commons Attribution (CC BY) license (https:// creativecommons.org/licenses/by/ $4.0 /)$.
6 Department of Clinical Pharmaceutics, University of Greifswald, Felix-Hausdorff-Str. 1, 17489 Greifswald, Germany; ritter@uni-greifswald.de

7 Department of Cancer Immunology and Virology, Dana-Farber Cancer Institute, Harvard Medical School, Boston, MA 02215, USA

* Correspondence: sander.bekeschus@inp-greifswald.de

$+\quad$ These authors equally contributed as first authors.

$\ddagger \quad$ These authors equally contributed as second authors.

Simple Summary: Despite treatment advances, glioblastoma multiforme (GBM) remains an oftenfatal disease, motivating novel therapeutic avenues. Gas plasma is a technology that has been recently employed in preclinical oncology research and acts primarily via reactive oxygen-species-induced cell death. In addition, the modulation of immune processes and inflammation have been ascribed to gas plasma exposure. This is the first study that extends those observations from in vitro investigations to a set of 16 patient-derived GBM tumor biopsies analyzed after gas plasma treatment ex vivo. Besides cell culture results showing cell cycle arrest and apoptosis induction, an immunomodulatory potential was identified for gas plasma exposure in vitro and cultured GBM tissues. The proapoptotic action shown in this study might be an important step forward to the first clinical observational studies on the future discovery of gas plasma technology's potential in neurosurgery and neuro-oncology.

Abstract: Glioblastoma multiforme (GBM) is the most common primary malignant adult brain tumor. Therapeutic options for glioblastoma are maximal surgical resection, chemotherapy, and radiotherapy. Therapy resistance and tumor recurrence demand, however, new strategies. Several experimental studies have suggested gas plasma technology, a partially ionized gas that generates a potent mixture of reactive oxygen species (ROS), as a future complement to the existing treatment arsenal. However, aspects such as immunomodulation, inflammatory consequences, and feasibility studies using GBM tissue have not been addressed so far. In vitro, gas plasma generated ROS that oxidized cells and led to a treatment time-dependent metabolic activity decline and G2 cell cycle arrest. In addition, peripheral blood-derived monocytes were co-cultured with glioblastoma cells, and immunomodulatory surface expression markers and cytokine release were screened. Gas plasma treatment of either cell type, for instance, decreased the expression of the M2-macrophage marker CD163 and the tolerogenic molecule SIGLEC1 (CD169). In patient-derived GBM tissue samples 
exposed to the plasma jet kINPen ex vivo, apoptosis was significantly increased. Quantitative chemokine/cytokine release screening revealed gas plasma exposure to significantly decrease 5 out of 11 tested chemokines and cytokines, namely IL-6, TGF- $\beta$, sTREM-2, b-NGF, and TNF- $\alpha$ involved in GBM apoptosis and immunomodulation. In summary, the immuno-modulatory and proapoptotic action shown in this study might be an important step forward to first clinical observational studies on the future discovery of gas plasma technology's potential in neurosurgery and neuro-oncology especially in putative adjuvant or combinatory GBM treatment settings.

Keywords: brain tumor; chemokines; cytokines; cold physical plasma; reactive oxygen species

\section{Introduction}

Glioblastoma multiforme (GBM) is characterized as a WHO-grade-IV tumor and, therefore, a highly aggressive primary brain tumor. GBMs are among the most malignant brain tumors and have a poor outcome with a median survival of only 14 months. The 5 -year overall survival is meager, with an average of $4-6 \%$ [1]. The current standard of care is maximal surgical resection, adjuvant chemotherapy, and radiotherapy. GBM is typically characterized by strong resistance to apoptosis by radiation and chemotherapeutic treatment regimens [2]. Due to the limited success of treatment, the development of new therapeutic strategies is indispensable.

In recent years, gas plasma technology has been heavily investigated as a novel anticancer agent [3]. It became evident that the local deposition of a plethora of reactive oxygen and nitrogen species (ROS/RNS) is the principal mechanism by which gas plasmas mediate biological effects, including apoptosis in cancer cells [4]. Intriguingly, certified medical plasma technology, such as the kINPen as the only example of an approved plasma jet, is operated at body temperature [5], sparing vital tissue from thermal damage. At the same time, plasmas jets can be operated by surgeons like a knife, with a high precision achievable for the tissue to be targeted. Moreover, the jet plasma seamlessly enters microcavities that would not be penetrated with flat-surface plasma sources. This array of reasons motivated us to provide a proof-of-concept study on the plasma jet kINPen for targeting glioblastoma. This was supported by the fact that several in vitro studies have investigated the effects of direct gas plasma exposure and treatment with plasma-treated liquids in different GBM cell lines in vitro [6-9] and-non-orthotopically-in vivo [10-12]. Some studies have also investigated the combination of gas plasma with drug treatment [13-15].

In solid cancers in general, and GBM specifically, not only the tumor cells themselves but also their surrounding are therapeutic targets. The composition of this micro milieu, called the tumor microenvironment (TME), has been found to dictate the outcome of many types of therapies in GBM and other cancers [16,17]. With the arrival of cancer immunotherapies entering most oncological treatment schemes, there is also an increasing understanding of the critical role of tumor-infiltrating leukocytes and median survival, as these leukocytes may perform direct tumor-toxic or promoting action by cellcell-interactions or the release of soluble mediators, such as chemokines, cytokines, and growth factors [18-20]. GBM in particular is known to acquire therapy resistance quickly. Moreover, GBM is often heavily infiltrated with tumor-associated macrophages (TAM) and microglial cells that promote tumor growth [21]. To this end, it is not only important to learn how a therapeutic approach affects tumor cells but also how it affects cells of the immune system as well as how therapeutically targeted tumor cells signal into the TME and vice versa $[16,22]$.

The current study aimed to provide a proof-of-concept preclinical study on employing a gas plasma jet-based anti-GBM approach, taking into account the many facets of such a strategy, among them (i) showing the principal ROS-generating nature, (ii) providing a basic understanding of toxicity based on cell cycle arrest, (iii) deciphering the immunomodulatory features by using plasma co-culture models, and (iv) elucidating the toxicity and 
effects on chemokine and cytokine as well as growth factor secretion following gas plasma exposure to primary patient-derived glioblastoma tissue biopsies ex vivo. By including 16 diseased individuals in our study, this is the first time the proapoptotic nature of gas plasma treatment was shown in human glioblastoma samples. These results could be helpful to target surgical margins after GBM excision to reduce disease recurrences.

\section{Materials and Methods}

\subsection{Cell Culture}

Non-malignant HaCaT keratinocytes (ATCC: PCS-200-011) and malignant T98G (ATCC: CRL-1690) and U87 (ATCC: HTB-14) glioblastoma cell lines were cultured up to passage number 15 from the original stock under standard conditions at $37^{\circ} \mathrm{C}, 5 \% \mathrm{CO}_{2}$, and $95 \%$ humidity in a sterilizable cell culture incubator (Binder, Stuttgart, Germany). Cells were maintained in a fully supplemented Roswell Park Memorial Institute (RPMI) 1640 cell culture medium supplemented with fetal bovine serum $(10 \%)$, glutamine $(2 \%)$, and penicillin-streptomycin (1\%). Cells received fresh medium twice to thrice per week and were sub-passaged usually once a week using trypsinization.

\subsection{Monocyte Isolation}

Peripheral blood was obtained from venipuncture from four donors upon informed consent. Peripheral blood mononuclear cells (PBMC) were obtained as described [23]. Briefly, blood was layered above a high-density glucose solution, followed by centrifugation without a break, PBMC collection, and hypotonic lysis of contaminating red cells. Subsequently, $\mathrm{CD} 14^{+}$monocytes were isolated by magnetic bead purification based on a negative selection kit (Miltenyi Biotec, Teterow, Germany).

\subsection{Glioblastoma Multiforme (GBM) Tissue Biopsies}

Brain tumor tissue biopsies were collected from 16 patients (4 female and 12 male, mean age 67 (range: 41-85 years)) who were radiologically suspected to have glioblastoma multiforme. The diagnoses were later confirmed by the Institute of Pathology in Greifswald, Germany. The tumor samples were removed intraoperatively with tumor-grasping forceps. Depending on operability, several biopsies of different areas were taken in the surgical theater and transported in $0.9 \%$ physiological sodium chloride solution to the laboratory. One or several punch biopsies (diameter: $5 \mathrm{~mm}$ ) were generated from each tissue sample. This way, several technical replicates could be treated and analyzed from each sample type. Sample culturing was done by transfer into 24-well plates containing cell culture medium and incubated under standard culture conditions. Twenty-four hours later, supernatants were collected and stored at $-80{ }^{\circ} \mathrm{C}$. Tissues were embedded in Tissue Tek Cryomold (Sakura Finetek, Staufen, Germany) in disposable base molds (Thermo Fisher Scientific, Bremen, Germany), snap-frozen in liquid nitrogen, wrapped in aluminum foil, and stored at $-80{ }^{\circ} \mathrm{C}$.

\subsection{Gas Plasma Treatment}

The atmospheric pressure argon plasma jet kINPen was utilized for gas plasma jet exposure. The technical properties of the device have been extensively described previously [24]. The jet was operated using 3 standard liters per minute of argon gas (purity: 99.999\%; Air Liquide, Bremen, Germany). In some in vitro experiments, the argon gas was humidified before being fed into the jet, as described before [25]. As an additional iteration in the in vitro studies, a surface dielectric barrier discharge (DBD) was utilized as outlined previously [26]. The kINPen operated with dry or humid (wet) argon or the DBD was placed above a $60 \mathrm{~mm}$ dish containing $5 \mathrm{~mL}$ of fully supplemented cell culture medium, operated for the given exposure time, which was subsequently transferred to the cells. For gas plasma exposure in the co-culture experiments, only $30 \mathrm{~s}$ of kINPen treatment (with dry argon) of either monocytes or tumor cells $\left(2 \times 10^{4}\right.$ per well of a 24-well plate) was performed. For gas plasma exposure of the patient-derived GBM samples, the 
tissue biopsies were placed into small tips that were subsequently added to the wells of a 96-well plate. This way, a computer-programmed $x y z$ table (CNC, Prenzlau, Germany) with the kINPen attached was able to gas plasma-treat several samples at a similar height and location (central to the tissue sample) for $120 \mathrm{~s}$. The treatment was performed within $2 \mathrm{~h}$ postsurgery in the laboratory before a $18 \mathrm{~h}$ incubation period at $37^{\circ} \mathrm{C}$. All control samples remained untreated.

\subsection{ROS and Metabolic Activity Analysis}

For in vitro experiments and results, hydrogen peroxide $\left(\mathrm{H}_{2} \mathrm{O}_{2}\right)$ is a primary biological mediator of gas plasma effects in liquids in contact with cells [27]. $\mathrm{H}_{2} \mathrm{O}_{2}$ was quantified in the gas plasma-treated cell culture medium (without cells) within 30 min after treatment as described in the manufacturer's protocol of the Amplex Red kit (Thermo Fisher, Bremen, Germany). Subsequently, the plate was added to a bandpass-filter-based microplate reader (F200; Tecan, Männedorf, Schweiz), and the wells' fluorescence was quantified with $\lambda_{\mathrm{ex}}$ $560 \mathrm{~nm}$ and $\lambda_{\mathrm{em}} 590 \mathrm{~nm}$. Prior to assessing intracellular ROS increase, $1 \times 10^{4} \mathrm{HaCaT}$ or T98G cells were added to each well of a 96-well plate and were allowed to adhere overnight. The next day, the medium was aspirated, and the cells were stained with $\mathrm{H}_{2}$-DCF-DA according to the vendor's instructions (Thermo Fisher, Bremen, Germany). Fresh untreated or gas plasma-treated medium was added, followed by quantification in the microplate reader with $\lambda_{\mathrm{ex}} 485 \mathrm{~nm}$ and $\lambda_{\mathrm{em}} 525 \mathrm{~nm} 30 \mathrm{~min}$ later. For analyzing metabolic activity, $2.5 \times 10^{3}$ cells were seeded in 96-well plates and allowed to adhere overnight. The next day, the medium was replaced with fresh untreated or gas plasma-treated medium. Then, $68 \mathrm{~h}$ later, resazurin (final concentration: $100 \mu \mathrm{M}$; Thermo Fisher, Bremen, Germany) was added, and the cells were incubated for another $4 \mathrm{~h}$ at $37^{\circ} \mathrm{C}$. Then, the 96 -well plate was transferred to the microplate reader, and fluorescence was quantified at $\lambda_{\text {ex }} 560 \mathrm{~nm}$ and $\lambda_{\mathrm{em}} 590 \mathrm{~nm}$.

\subsection{Cell Cycle Analysis}

For cell cycle analysis, $5 \times 10^{4}$ cells per well of a 24 -well plate were exposed to gas plasma-treated medium. Twenty-four hours later, cells were collected, washed, fixed, and permeabilized with ice-cold ethanol, incubated with RNAse, and stained with propidium iodide (final concentration: $10 \mu \mathrm{g} / \mathrm{mL}$; ThermoFisher, Bremen, Germany). After washing, samples were acquired using flow cytometry (Gallios; Beckman Coulter, Krefeld, Germany). Sample analysis was carried out using Kaluza 2.1 software (Beckman Coulter, Krefeld, Germany), and the integrated FOX algorithm was used to retrieve the percentage of cells in the G1, S, and G2 phases from mathematical modeling of doublet-cleared input gates.

\subsection{Co-Culture and Multicolor Surface Marker Flow Cytometry}

Co-cultures of human peripheral blood-derived monocytes and T87MG GBM cells were set up in 24-well plates with $2 \times 10^{4}$ cells of each entity in $500 \mu \mathrm{L}$ of fully supplemented cell culture medium. Specifically, $2 \times 10^{4}$ cells of one entity was added to the wells, followed by gas plasma treatment (30 s) of this suspension. Four hours later, the complementary cell (U87 GBM cells to gas plasma-treated monocytes; monocytes to gas plasma-treated GBM cells) type was added in $500 \mu \mathrm{L}$ of cell culture medium. After co-culture incubation for at least $48 \mathrm{~h}$, the supernatant was collected and stored for later longitudinal analysis, and the cells were harvested using trypsin. After washing, the cells were incubated with different fluorescently labeled monoclonal antibody master mixes that targeted (some of) the following molecules: cluster of differentiation (CD)11, CD14, CD45, CD55, CD97, CD162, CD169, CD204, CD276, HLA-ABC, and HLA-DR. Isotype controls were IgG1, IgG2a, IgG2b, and REA antibodies. The antibodies were labeled with different fluorophores, such as phycoerythrin (PE), peridinin-chlorophyll-protein Complex (PerCP), Fluorescein-5isothiocyanate (FITC), allophycocyanin (APC), PE-Vio770, PerCP-Vio700, and VioBrightFITC. A Tandem signal enhancer in running buffer was added to all samples. After staining, samples were washed in running buffer, resuspended in running buffer, and acquired 
using flow cytometry (MACS-Quant10). 4',6-Diamidin-2-phenylindol (DAPI) was used to label terminally dead cells. All material was supplied by Miltenyi Biotec, Bergisch Gladbach, Germany.

\subsection{Multiplex Chemokine and Cytokine Analysis}

Multiplex chemokine, cytokine, and growth factor quantification was performed using a bead-based assay (BioLegend, Amsterdam, The Netherlands) according to the vendor's instructions. Briefly, supernatants of the in vitro co-culture assays and ex vivo GBM tissue cultures were incubated with beads, and mean fluorescence intensities (MFI) of each bead population (representing a single analyte) were determined using flow cytometry (CytoFLEX S; Beckman Coulter, Krefeld, Germany). Total analyte concentrations were calculated in picogram per milliliter against a known standard using 5-log fitting with dedicated VigeneTech software. Statistical analysis was performed by parametric paired $t$-tests for each analyte and donor.

\subsection{Tissue Sections and Immunofluorescence Staining, Imaging, and Analysis}

The tissue samples were sectioned vertically (thickness: $5 \mu \mathrm{m}$ ) $90^{\circ}$ to the gas plasmatreated side (facing up) on Superfrost plus slides (Thermo Fisher, Bremen, Germany) and stored at $-80{ }^{\circ} \mathrm{C}$ until further staining. Prior to staining, the sections were fixed in $4 \%$ paraformaldehyde (Carl Roth, Karlsruhe, Germany) and washed three times for five minutes in phosphate-buffered saline (PBS). Cell membrane permeabilization was performed for two minutes using 0.25\% Triton X-100 (Carl Roth, Karlsruhe, Germany) followed by three washing periods of five minutes in PBS. The TUNEL kit (Roche Diagnostics, Basel, Switzerland) was used for apoptosis detection as per the manufacturer's instructions. The slides were incubated for one hour at $37{ }^{\circ} \mathrm{C}$ in a humidified chamber. The sections were washed three times in PBS followed by DAPI addition to counterstain nuclei. The slides were mounted with Fluoromount Aqueous Mounting Medium (Sigma-Aldrich, Taufkirchen, Germany). Imaging and analysis were performed using a high-content imaging device (Operetta CLS; PerkinElmer, Hamburg, Germany) and its associated software (Harmony 4.9; PerkinElmer, Hamburg, Germany). Quantification was based on algorithmdriven object segmentation.

\subsection{Statistical Analysis}

Prism 9.3 (GraphPad Software, San Diego, CA, USA) was used for graphing and statistical analysis. The details of statistical analysis are given in the figure legends. Level of significance is indicated as follows: $\alpha=0.05\left({ }^{*}\right), \alpha=0.01\left({ }^{* *}\right)$, and $\alpha=0.001\left(^{* * *}\right)$.

\section{Results}

\subsection{Metabolic Activity Decline and Cell Cycle Rest of Glioblastoma Monocultures In Vitro}

To analyze the efficacy of gas plasma technology in vitro, different plasma setups were tested to treat cells (Figure 1a). The idea was to show that different plasma source approaches may be able to perform a similar task. Both the DBD and the jet-generated $\mathrm{H}_{2} \mathrm{O}_{2}$ as a representative long-lived oxidant in an exposure-time-dependent fashion (Figure 1b). The plasma jet's chemistry can be optimized by, e.g., changing the feed gas composition. Accordingly, humidified argon gas extended the $\mathrm{H}_{2} \mathrm{O}_{2}$ generation compared to the dry condition. The oxidants introduced by the plasma sources oxidized the treated cells, as evidenced by increased DCF intensities (Figure 1c). Next, the dry jet's ability to reduce the cells' metabolic activity (Figure 1d) was used. HaCaT keratinocytes were exposed either once or several times to the plasma-treated medium (LT) with passaging in between serving as a non-malignant control compared to T98G GBM cells. The apoptosis-induced etoposide (Eto, positive control) was effective in HaCaT but only to a minor extent in the malignant T98G cells (Figure 1e). Interestingly, the $60 \mathrm{~s}$ gas plasma condition conferred only minor toxicity in GBM cells as well, while it was significantly more toxic in HaCaTs. Longer plasma exposure times (120 s) were toxic in both cell types. To study the consequences of gas 
plasma-generated ROS/RNS on proliferative capacity, cell cycle analysis was performed in T98G (Figure 1f) and HaCaT keratinocytes (Figure 1g). For all plasma treatment approaches, a prominent G2 arrest was observed (left histograms). Mathematical modeling (Michael H. Fox algorithm) of cell cycle phases and quantification supported this notion (middle). The largest percentage of cells observed in the G2 phase was found for the longest jet treatment (dry) in both cell lines. Spaghetti plots (right) illustrate the conversion of a G1-phase dominated into a G2-phase dominated cellular phenotype. In terms of absolute changes from the original state, this was much more pronounced in GBM cells (G1: $-32.1 \%$, G2: $+23.8 \%$ ) than in HaCaTs (G1: $-14.4 \%$, G2: $+16.4 \%)$.

\subsection{Immunomodulation in Gas Plasma-Treated Monocyte-GBM Co-Cultures}

To analyze the immunomodulatory effect of gas plasma treatment, peripheral bloodderived monocytes were isolated and co-cultured with GBM cells. Either the monocytes or the GBM cells were exposed to gas plasma, followed by the addition of the complementary cell type afterward. The surface marker expression of monocytes was investigated using multicolor flow cytometry, and the co-cultures' supernatants were quantitatively assessed for chemokine, cytokine, and growth factor release (Figure 2a). Monocultures of monocytes served as control. Sufficient numbers of viable monocytes were measured in the different conditions to assess their surface marker profiles (Figure $2 b$ ). Gas plasma exposure of monocytes $\left(\mathrm{M}_{\mathrm{P}}\right)$ compared to monocytes alone $(\mathrm{M})$ only had a minor effect on the cells. A subtle but significant decrease was observed for CD11 and CD14, both being macrophage differentiation markers (but usually regulated at much greater amplitude), as well as CD55 being an activation marker and CD276 (B7-H3), a prominent immunosuppressant, apart from CD169. Significant and somewhat greater changes were observed between the monoculture and co-culture of monocytes with GBM cells, as seen by a significant increase in CD11, CD14, CD55, CD97, CD162, CD163, CD169, and CD204. CD162 (PSGL-1) is a pro-atherogenic marker as it binds platelets, CD163 is a marker of tumor-supporting macrophages, CD169 defines tolerogenic (anti-inflammatory) monocytes binding to red cells, CD97 is an EGF-TM7 receptor, and pattern-recognition-receptor CD204 engagement is pro-inflammatory. The co-culture of gas plasma-treated monocytes with GBM cells gave a modest but significant decrease in CD14, CD97, CD163, and CD169 expression, while CD276 expression was significantly increased. In case of gas plasma-treated GBM cells subsequently co-cultured with monocytes, a significant decrease in CD14, CD163, and CD169 was observed on monocytes. These results indicate functional changes of monocytes with gas plasma exposure, albeit the overall amplitudes of changes were moderate. However, a monovalent response type could not be identified, as both activation and suppression markers were regulated in favor and disfavor of anti-tumor activity simultaneously. Next, the release of chemokines, cytokines, and growth factors was quantified (Figure 2c). Again, the co-culture was markedly different from monocyte monocultures, especially IL-6 (Interleukin), IL-8, IL-23, and MCP-1 (monocyte chemoattractant protein 1). Our study could not establish whether these analytes were a product of the tumor cells or the monocytes affected by the tumor cells due to the lack of GBM monocultures. In co-cultures, gas plasma exposure to monocytes significantly increased IL-6 and IL-8 levels, while the levels of all other released factors did not change significantly. IL-8 has a great degree of pleiotropy in health and disease, including cancer. In summary, gas plasma treatment was perceived by the monocytes and affected their phenotype and the inflammatory mediator release profile in co-cultures with GBM cells. 
a

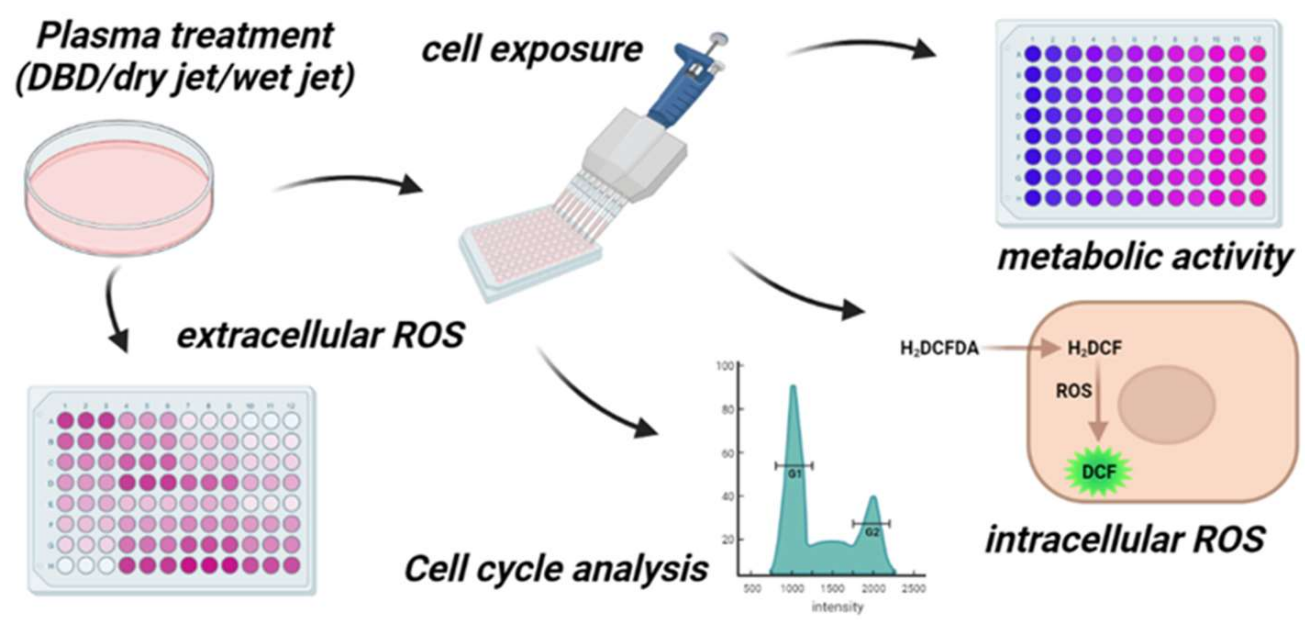

b

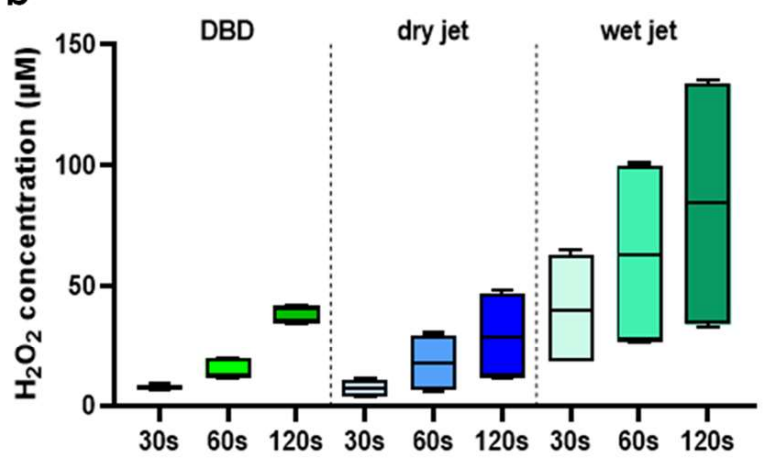

C

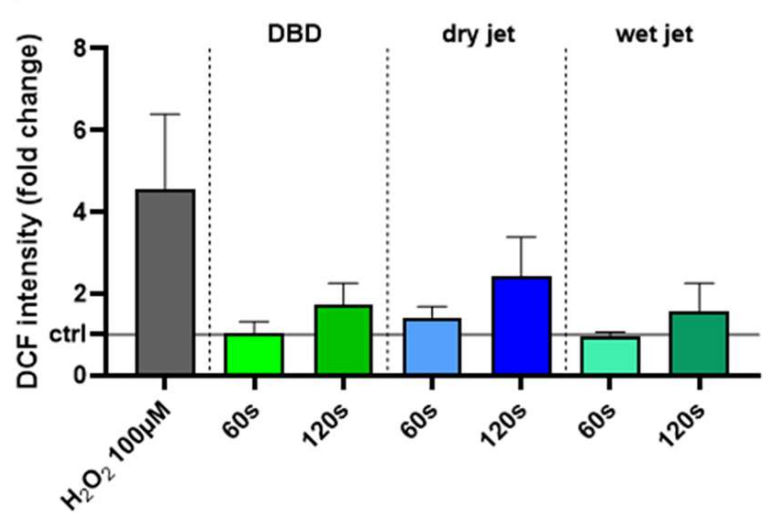

d

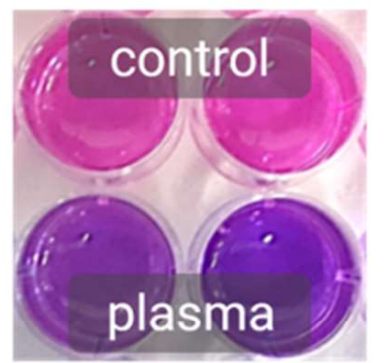

e

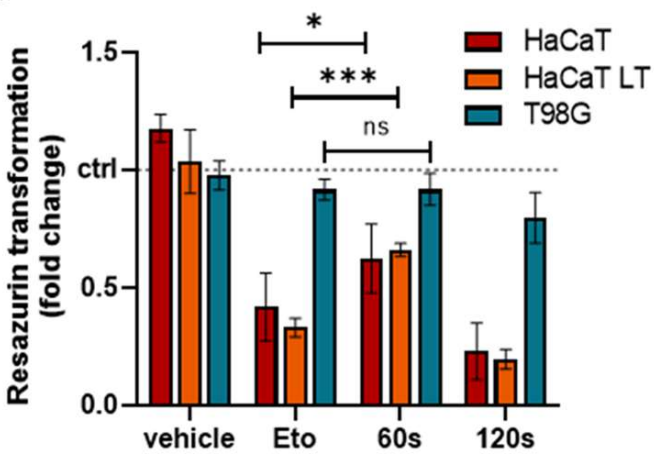

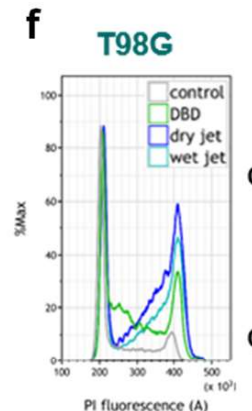

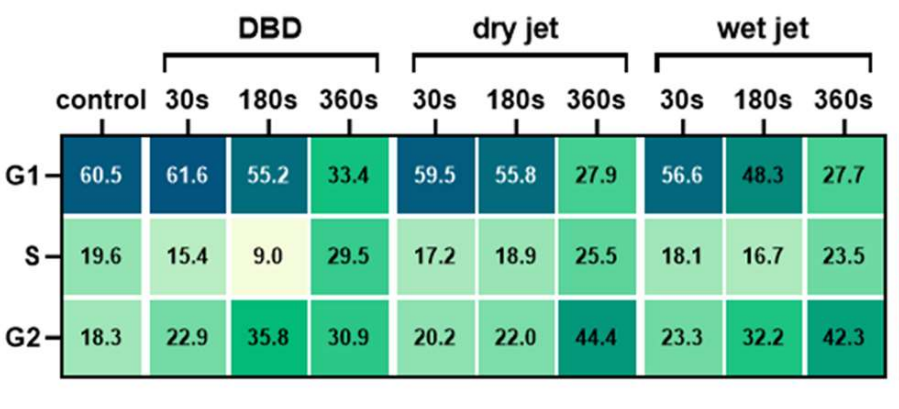

$\%$ gated

dry jet

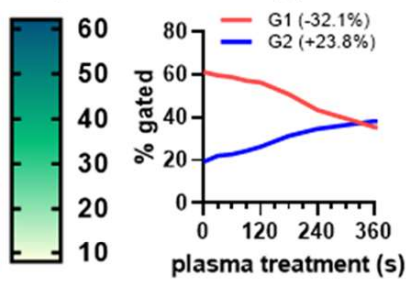

Figure 1. Cont. 


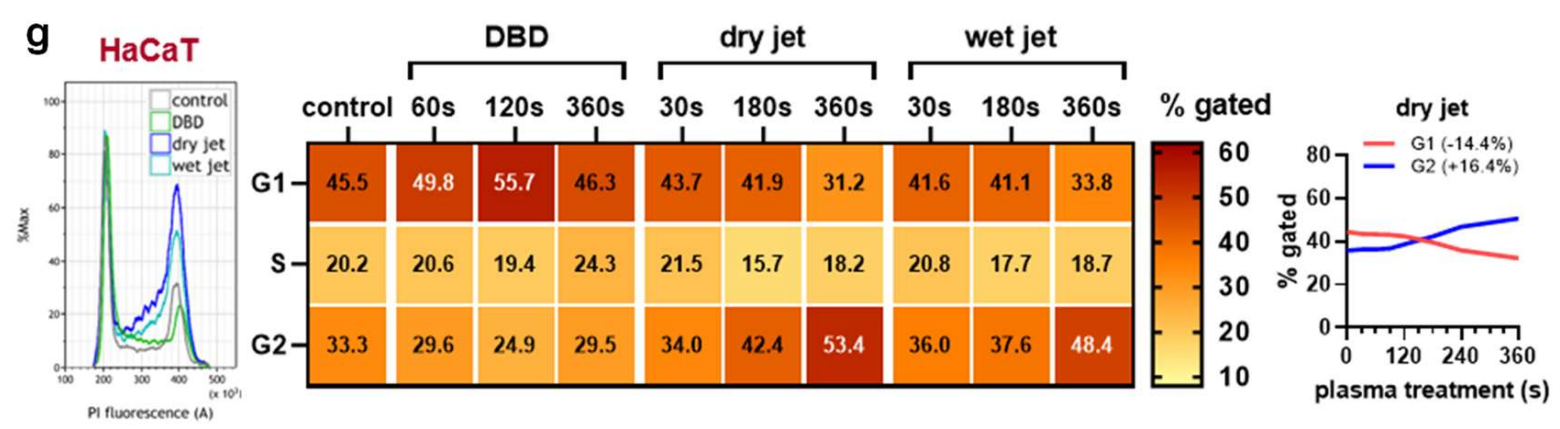

Figure 1. Metabolic activity decline and cell cycle rest of glioblastoma monocultures in vitro. (a) study scheme; (b) $\mathrm{H}_{2} \mathrm{O}_{2}$ generation by the DBD and the jet operated with dry and humid (wet) argon gas; (c) cellular oxidation as indicated by DCF fluorescence upon exposure to plasma-treated media; (d,e) representative macroscopic image of the resazurin assay (d) and metabolic activity quantified and normalized (e) against each untreated control for HaCaT keratinocytes, HaCaTs with a history of plasma exposure and passaging (LT) and malignant T98G GBM cells; (f,g) representative flow cytometry overlay histograms of propidium iodide (PI) fluorescence (left), quantification of cell cycle phases using mathematically modeling (middle), and spaghetti plots of the same data visualizing G1 to G2 ratios for T98G (f) and HaCaT (g) cells. Data are representative of boxplot or mean and standard error of three experiments; statistical analysis was performed using unpaired, two-tailed $t$-test with $p<0.05\left(^{*}\right)$ and $p<0.001\left(^{* * *}\right)$ differing significantly or non-significantly (ns).

a

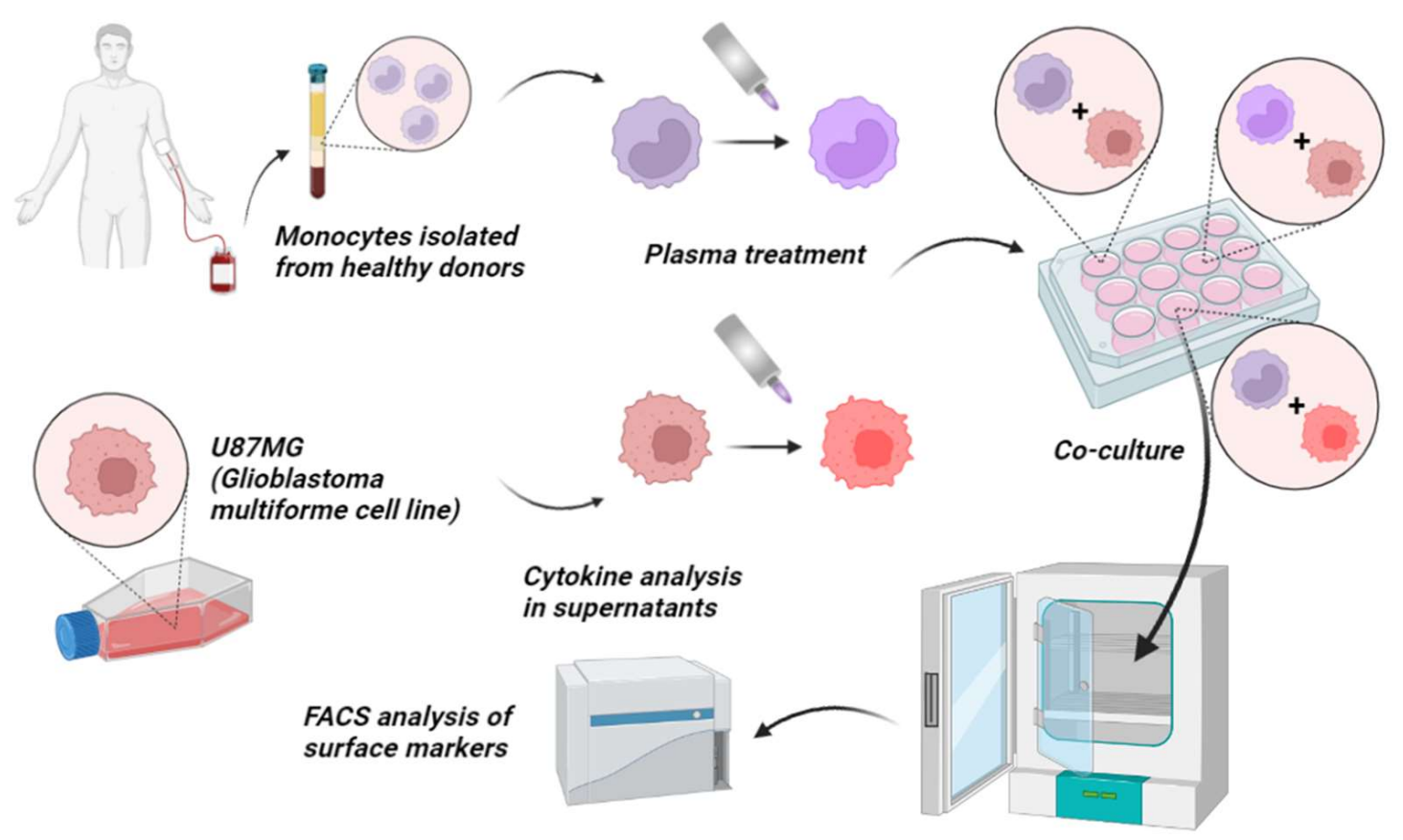

Figure 2. Cont. 
b
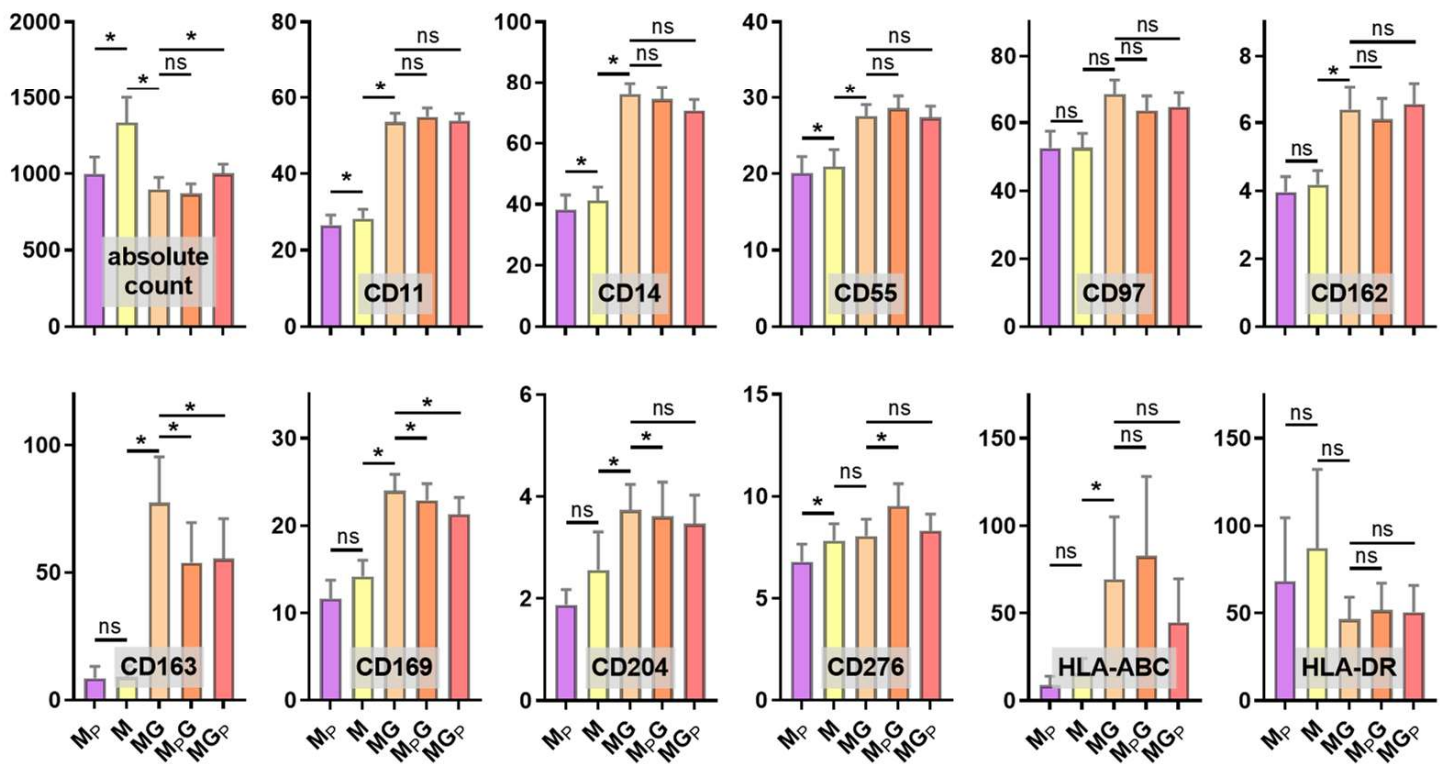

C
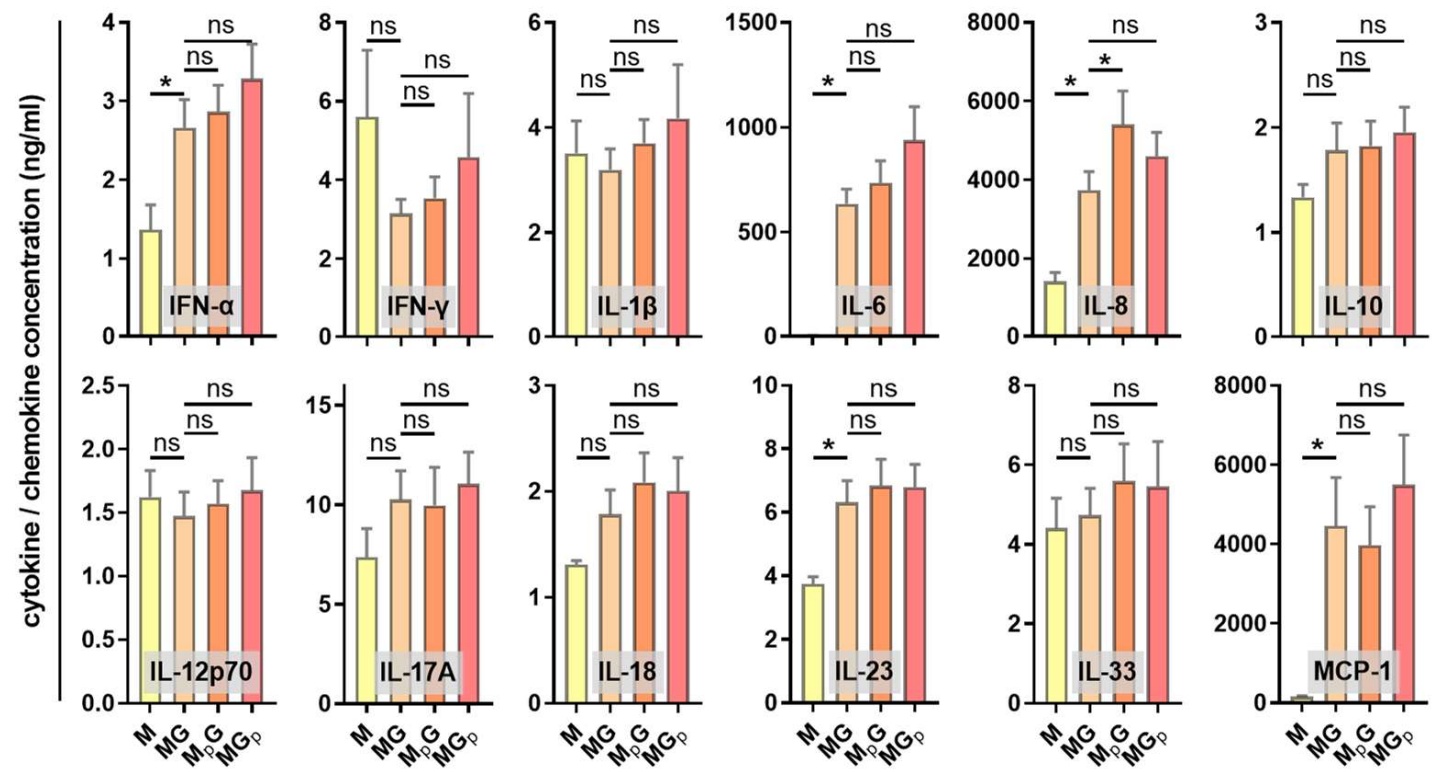

Figure 2. Monocyte surface marker expression and cytokine release profiles in GBM cultures (a) Study protocol; (b) absolute viable monocyte counts and median fluorescence intensities of monocytes $(\mathrm{M})$, gas plasma-treated monocytes $\left(\mathrm{M}_{\mathrm{P}}\right)$, monocyte-GBM co-cultures $(\mathrm{MG})$, gas plasmatreated monocytes co-cultured with GBM $\left(\mathrm{M}_{\mathrm{P}} \mathrm{G}\right)$, and gas plasma-treated GBM cells co-cultured with monocytes (MGP) as determined using multicolor flow cytometry; (c) cytokine, chemokine, and growth factor release quantification in monocyte monoculture and co-culture supernatants. Data are mean and standard error of monocytes from four donors; statistical analysis was performed using two-tailed Wilcoxon rank test with $p<0.05\left(^{*}\right)$ differing significantly or non-significantly (ns).

\subsection{Analysis of Gas Plasma-Treated Patient-Derived GBM Tissue}

The next question was whether gas plasma exposure affected patient-derived glioblastoma multiforme tissue biopsies ex vivo. Following the treatment, the tissues were cultured for $24 \mathrm{~h}$ before tissue section and secretion profile analysis (Figure 3a). TUNEL staining indicative of apoptotic cells was performed, and sections were imaged and analyzed by fluorescence microscopy and algorithm-driven quantitative image analysis. Gas plasma exposure led to strongly apoptotic regions in the GBM tissues when compared to untreated 
controls (Figure 3b). Quantitative analysis revealed a significantly greater presence of apoptotic cells in gas plasma-treated tissue than controls (Figure 3c). In the context of gas plasma treatment, ROS are not only known to increase cell death but also to modulate inflammation within the tumor. Hence, in the supernatants of these untreated and gas plasma-treated and cultured GBM tissue biopsies, an array of cytokines, chemokines, and growth factors was detected. The concentrations of several targets were significantly modulated by gas plasma exposure (Figure 4). TREM-1 (triggering receptor expressed on myeloid cells 1), BDNF (brain-derived neurotrophic factor), IL-18, TGF- $\beta$ (tumor growth factor beta), TNF- $\alpha$ (tumor necrosis factor-alpha), and b-NGF (nerve growth factor beta) showed an overall low expression regardless of the treatment group. In turn, IL-6, VEGF (vascular endothelial growth factor), MCP-1, VILIP- $\alpha$ (visinin-like protein alpha/1), and sTREM-2 (soluble TREM2) were found to be released at modest to high levels. Ex vivo gas plasmas exposure of patient-derived primary glioblastoma tissue led to significantly decreased release levels of b-NGF, IL-6, sTREM2, TGF- $\beta$, TNF- $\alpha$, and TREM-1.

a

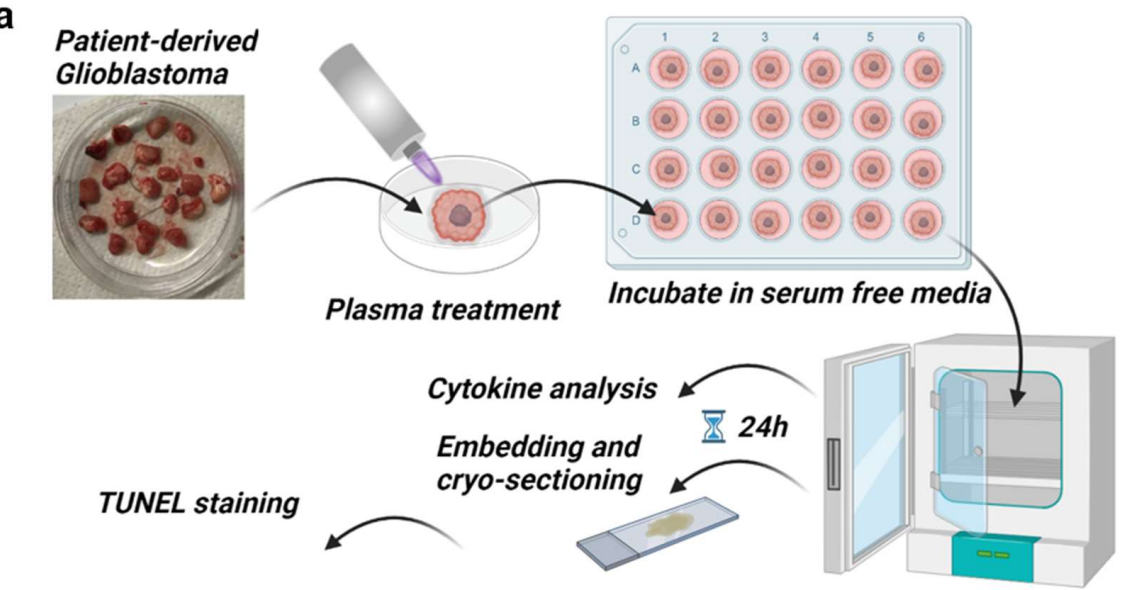

b
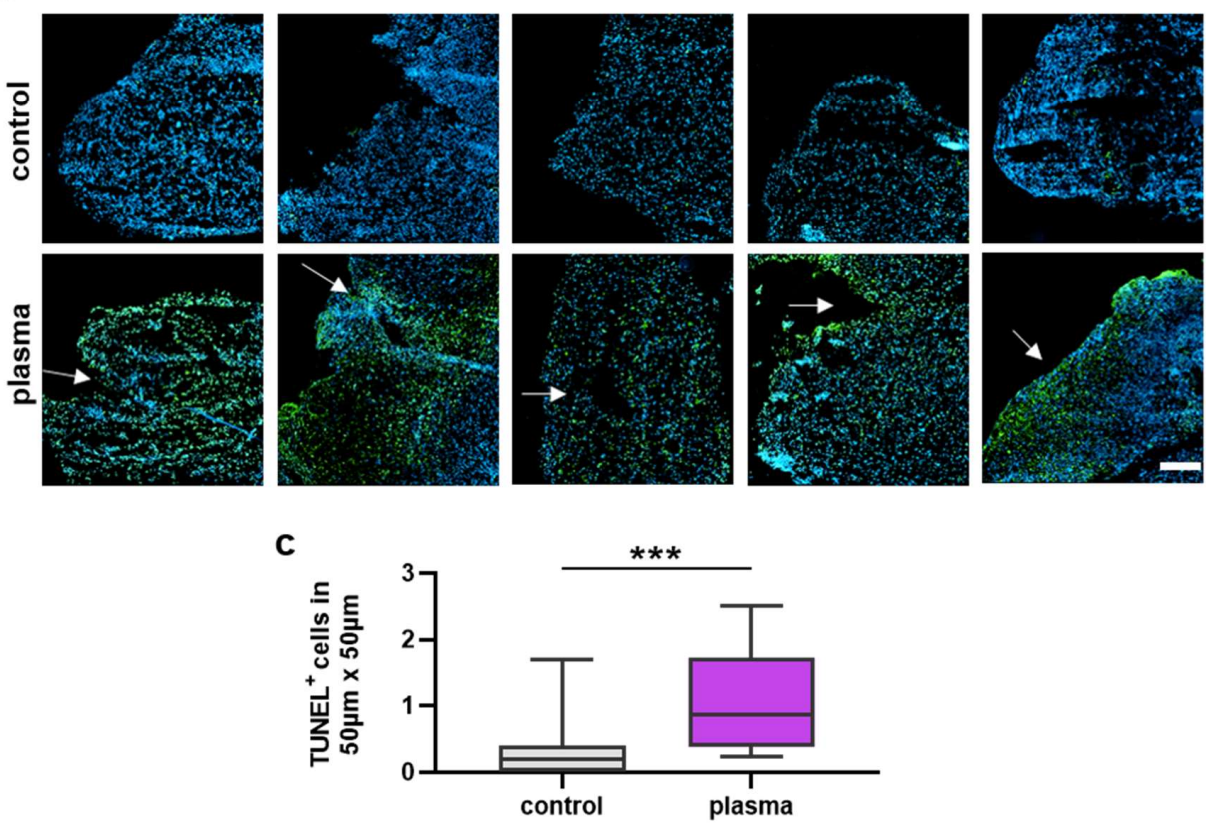

Figure 3. Patient-derived GBM tumor sample analysis. (a) Study protocol; (b) examples of highly apoptotic ( $\mathrm{TUNEL}^{+}$, green) patient-derived glioblastoma multiforme tissue ultrathin cryosections following gas plasma exposure (nuclei counterstained with DAPI in blue); (c) algorithm-driven quantitative image analysis of tissue sections for $\mathrm{TUNEL}^{+}$(apoptotic) cells per area. Data are box plots (Tukey) from 16 patient samples; statistical analysis was performed using two-tailed MannWhitney test with $\left.p<0.001{ }^{* * *}\right)$ differing significantly. Scale bar is $150 \mu \mathrm{m}$. 

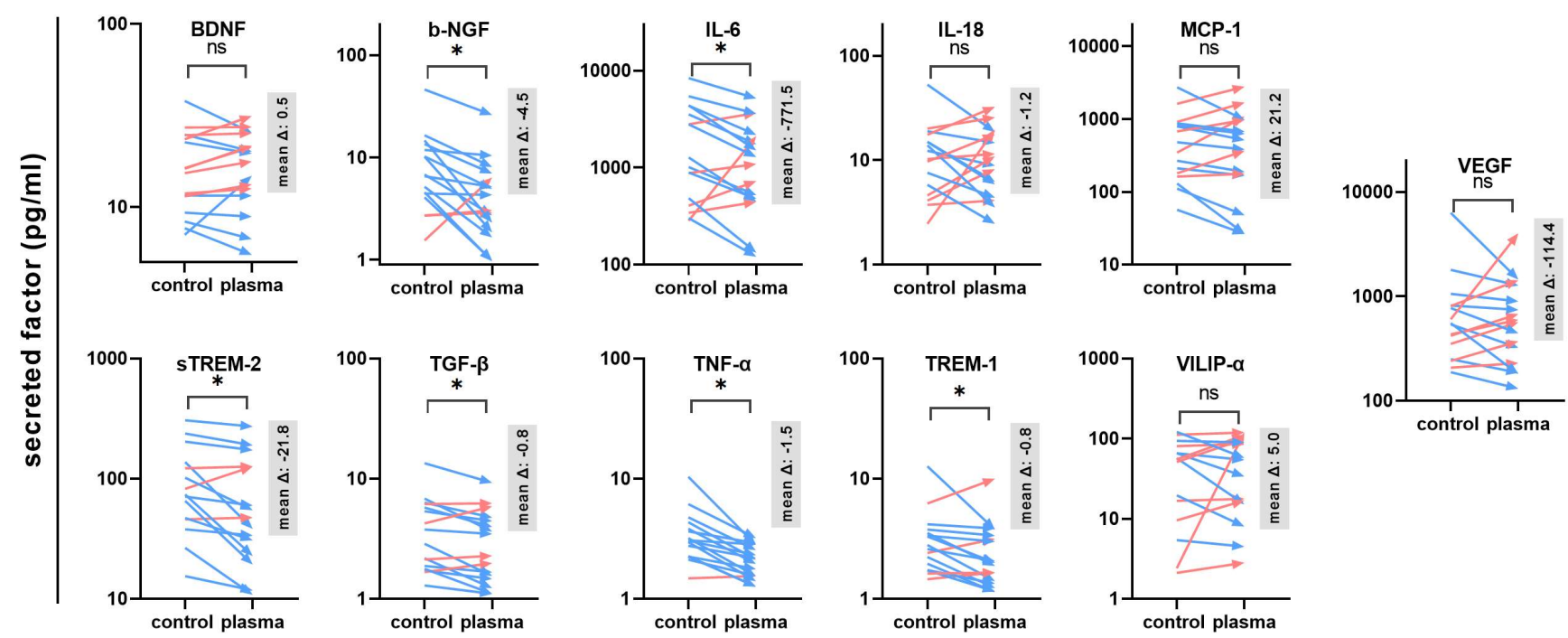

Figure 4. Secretion profiling of patient-derived GBM tissues. A total of 11 cytokines, chemokines, and growth factors were analyzed in the supernatants of untreated or gas plasma-treated patient-derived glioblastoma multiforme (GBM) tumor biopsies cultured for $24 \mathrm{~h}$. Data are from 15-16 donors and show mean of each donor and control and treatment group (red: increase, blue: decrease) with mean delta $(\Delta)$ given in gray boxes; statistical analysis was performed based on normality distribution using either a paired $t$-test or two-tailed Wilcoxon rank test with $p<0.05\left(^{*}\right)$ differing significantly or non-significantly (ns).

\section{Discussion}

Gas plasma technology is a promising new avenue in cancer treatment. Recent reports have suggested a role of this treatment in glioblastoma therapy [28], but data on immunomodulatory consequences and translational models are scarce, which is addressed in the current study.

Upon gas plasma exposure, we found robust induction of apoptosis in patient-derived glioblastoma tissue treated ex vivo. The programmed cell death in glioblastoma is a major target for therapeutic strategies. Apoptosis is caspase-controlled and is divided into an extrinsic and intrinsic pathway. The extrinsic pathway is regulated by activating the receptors TNF-R1 or FAS DR4/DR5, which leads to the recruitment of caspases 8 and 10 with subsequent activation of effector caspases (caspase 3). In contrast, intracellular ROS increase, such as that which occurs with gas plasma exposure, activates the intrinsic pathway, which causes a conformational change in the pro-apoptotic BCL-2 proteins BAK and BAX with subsequent cytochrome c release and activation of caspase 3 via caspase 9. Apoptosis resistance in glioblastoma is a problematic aspect of glioblastoma control. In part, it indicates the poor response to radio and chemotherapy, which could be enhanced by the intervention of the resistance processes [29]. Specifically, in recurrent GBM, the pro-survival proteins BCL-2 and BCL-X $\mathrm{L}_{\mathrm{L}}$ are found to be upregulated, while the pro-apoptotic BAX is downregulated [30]. Until now, there has been a lack of strategy to increase apoptosis above the level of known established therapies [29]. An intracellular ROS increase, elicited via the addition of gas plasma-generated ROS, might be a putative way of inducing apoptosis, as has been previously shown in melanoma cells [31]. Intriguingly, we have also found gas plasma-mediated apoptosis induction in patient-derived metastatic melanoma lesions previously [32]. We recently extended these findings to other skin cancers, namely squamous cell carcinoma and basal cell carcinoma [33]. Additionally, primary-patientderived breast cancer cells were demised in response to gas plasma treatment [34]. While controlled multipatient cancer studies using this technology are still awaited, these ex vivo results together with first case report collections [35] might motivate future clinical research on different tumor entities, including GBM. Promising in vivo findings in an orthotopic 
GBM mouse model by the group of Michael Keidar encourages research to continue on this path [10]. Strikingly, they also reported on the additive cytotoxic effects of gas plasma and Temozolomide treatment in vivo [11], a cytostatic drug used in GBM therapy. Another study found that in vitro gas plasma-treated U87 cells developed smaller tumors in vivo than untreated cells [36].

The tumor microenvironment (TME) in glioblastoma is known for its complexity. Besides apoptosis resistance, the TME composition is another reason for the lack of success of different anti-GBM therapies [37,38]. Cytokines, chemokines, and growth factors that significantly influence the development and growth of the tumor also play a part in this. Therefore, we have investigated 11 different cytokines in their expression, which often play a major role in neuro-inflammatory pathologies. IL-6, TGF- $\beta$, TNF- $\alpha$, b-NGF, and sTREM-2 showed a significant reduction after gas plasma exposure. IL-6 has been shown to have a tumor-supportive effect. It promotes tumor growth and the migration of tumor cells in a similar fashion to a growth factor in glioblastoma $[39,40]$. In addition, IL-6 can block apoptosis and thus hamper therapeutic interventions [41]. Hence, a gas plasma-induced decreased release of IL- 6 might sensitize GBM cells to apoptosis. The alternatively activated tumor-associated macrophages (TAM) are considered controllers of the TME and support cancer growth. It has been shown that IL-6 knock-out inhibits alternative macrophage activation and thus increased survival in a murine GBM model [42]. For TNF- $\alpha$, evidence shows that this factor promotes anti-apoptotic effects [43]. Furthermore, TNF- $\alpha$ induces CCL2 (MCP-1), which is known for its immunosuppressive and pro-tumoral activity due to increased M2 (TAM) macrophage polarization [44]. In our study, however, the significantly decreased TNF- $\alpha$ upon the gas plasma treatment of GBM tissue did not correlate with significantly decreased MCP-1 levels. This might be due to differences in the cellular composition of the GBM tissue samples in terms of cells being the source of either factor, as MCP-1 can be released by both TAM and GBM cells $[45,46]$. In addition, tumor cells, including GBM, are known for their dysregulated signaling and epigenetic regulation, potentially resulting in TNF- $\alpha$-independent $\mathrm{MCP}-1$ release. TNF- $\alpha$ also promotes the JNK-Axl-ERK pathway $[47,48]$, which is known to induce resistance to EGFR therapy, an important strategy in GBM treatment [49]. b-NGF binds to the high affinity Tropomyosin receptor Kinase A (TrKA), which leads to amplified VEGF and thus increased angiogenesis, migration [50], apoptosis inhibition via p75NTR [51], and enhanced proliferation through the Notch1 signaling pathway [52]. Along similar lines, TGF- $\beta$ [53] and TREM-2 [54] elevated invasiveness and tumor growth in glioblastoma. TGF- $\beta$ also activates matrix metalloproteinases [55,56] and promotes the polarization of cancer-supporting TAM [57,58]. Altogether, the gas plasma-mediated reduction in these factors plays a role not only in GBM cell death but also in the immunomodulation of the GBM TME. The effects of plasma treatment show important approaches to developing new therapeutic strategies.

Our in vitro findings are in line with previously published evidence. Increased intracellular ROS and a decline in metabolic activity was noted in U87 cells by Cheng and colleagues using a helium-driven plasma jet [59] as well as plasma-treated media [60]. Akter and colleagues have also observed an increase in the G1 to G2 ratio of the cell cycle following gas plasma-exposed glioblastoma cells [36], as observed in our study. The authors also found GBM cells to be more sensitive to gas plasma exposure than non-malignant astrocytes [61]. Albeit our comparison cell line HaCaT derives from the skin and is less suitable as the control, its greater sensitivity to the gas plasma treatment is in line with previous findings that some tumor cell types are more sensitive to this non-malignant cell type while others are less sensitive [62], exemplifying that such comparisons are often relative. What is striking, however, is the finding that the cell cycle arrest observed in our study was found to be independent of the gas plasma source type and condition, underlining the general ROS-based nature of this treatment modality [4]. The main finding in our monocyte-GBM co-culture was a decline in CD163 and CD169 surface marker expression and increased release of IL-8. CD163 is a marker of anti-inflammatory M2 macrophages [63] supporting tumor growth [64]. SIGLEC1 (CD169) is thought to characterize regulatory myeloid 
cells participating in immunological tolerance and erythropoiesis [65]. Recent reports, however, suggest $\mathrm{CD} 169^{+}$monocytes contribute to antiviral defense, including COVID$19[66,67]$. Either way, our results do not point to an increased tumor-promoting phenotype, while the opposite cannot be concluded either as we did not investigate other markers of monocyte-to-macrophage differentiation and polarization. As microglia (macrophages) are an often-dominating immune cell type in the GBM TME, our experiments might be extended to monocyte-derived macrophages to resemble this situation closer in future studies. Regarding IL-8, there is clear evidence of its detrimental role in GBM pathogenesis and disease recurrence $[68,69]$. However, THP-1 monocytes were previously found to increase IL-8 expression and be released after gas plasma-induced intracellular ROS increase independently of the presence of tumor cells [70], which might have been the case in our study also.

Gas plasma technology generates multiple reactive species, which leads to ROS/RNS overload in target cells and tissues. According to Helmut Sies, oxidative stress is defined as a disturbance in the prooxidant-antioxidant balance in favor of the former [71]. At the time of gas plasma treatment, there is an immediate prooxidant surplus in the target cell and tissue, albeit the direct and dynamic measurement of such event, especially in tissues, remains technically challenging as of today. Cells, including GBM, have antioxidant enzymes to counteract ROS/RNS overload. Glutathione peroxidase 1 is a prototypical example in GBM [72]. Moreover, it has been proposed that oxidative stress, induced by pharmacological or technological means, sensitizes GBM to radiotherapy [73]. This concept has recently been extended to fat catabolism, fatty-acid-induced mitochondrial dysfunction, and oxidative stress with toxic consequences in GBM cells [74]. Additionally, sodium sulfide has been reported as a potential radiosensitizer in GBM [75]. However, combination treatments of gas plasma and ionizing radiation have so far only been tested for melanoma and breast cancer but not glioblastoma cells [76,77].

Some glioblastomas are inoperable due to their location in the brain because of the danger of damaging brain tissue which is vital to life or because of tumors being located at major brain blood vessels [78]. There are particularly critical localizations near the speech center (left temporal or mesencephalic tumors near the brainstem). Hence, gas plasma technology could be a strategy to mediate cytotoxic and immunomodulatory effects locally to GBM tissue, especially in areas not amenable to surgical resection such as the brainstem or other eloquent brain areas. In animal experiments, attempts have already been made to treat such non-resectable areas locally with chemotherapeutic drugs using cannulas [79]. However, locally applied chemotherapeutic agents can cause severe side effects and damage to the functionally important areas, whereas local plasma treatment has so far been void of any severe side effects in exposed human tissues.

\section{Conclusions}

Our proof-of-concept study provides evidence of a cytotoxic as well as immunomodulatory role of gas plasma exposure in glioblastoma in vitro and in patient-derived GBM tissue ex vivo. Hence, this technology might contribute to developing new therapeutic strategies in GBM management, especially as adjuvant treatment or in non-resectable areas.

Author Contributions: Conceptualization, S.B., K.W. and S.M.; methodology, S.B., M.I., E.F., M.B.S., K.W., C.A.R., H.W.S.S. and S.M.; software, S.B., E.F. and F.S.; validation, M.I., E.F., F.S., F.K. and D.S.; formal analysis, M.I., E.F., F.S., F.K. and D.S.; investigation, M.I., E.F., J.M., J.E. and F.K.; resources, S.B., C.A.R., H.W.S.S. and S.M.; data curation, M.I., F.S. and D.S.; writing-original draft preparation, S.B.; visualization, S.B., M.I. and D.S.; supervision, S.B., K.W. and S.M.; project administration, S.B.; funding acquisition, S.B. and S.M. All authors have read and agreed to the published version of the manuscript.

Funding: This research was funded by the German Federal Ministry of Education and Research, grant number 03Z22DN11 (to S.B.), the Gerhard Domagk Foundation Greifswald (to S.M.), and the Lieselotte-Beutel Foundation (Berlin, Germany). 
Institutional Review Board Statement: The study was conducted in accordance with the Declaration of Helsinki and approved by the Institutional Ethics Committee of the Greifswald University Medical Center (Germany, protocol code BB089/08b).

Informed Consent Statement: Informed consent was obtained from all subjects involved in the study.

Data Availability Statement: Data are available from the corresponding author upon reasonable request.

Conflicts of Interest: The authors declare no conflict of interest.

\section{References}

1. Cantrell, J.N.; Waddle, M.R.; Rotman, M.; Peterson, J.L.; Ruiz-Garcia, H.; Heckman, M.G.; Quinones-Hinojosa, A.; Rosenfeld, S.S.; Brown, P.D.; Trifiletti, D.M. Progress toward long-term survivors of glioblastoma. Mayo Clin. Proc. 2019, 94, 1278-1286. [CrossRef] [PubMed]

2. Wen, P.Y.; Kesari, S. Malignant gliomas in adults. N. Engl. J. Med. 2008, 359, 492-507. [CrossRef] [PubMed]

3. Dubuc, A.; Monsarrat, P.; Virard, F.; Merbahi, N.; Sarrette, J.P.; Laurencin-Dalicieux, S.; Cousty, S. Use of cold-atmospheric plasma in oncology: A concise systematic review. Ther. Adv. Med. Oncol. 2018, 10, 1758835918786475. [CrossRef] [PubMed]

4. Privat-Maldonado, A.; Schmidt, A.; Lin, A.; Weltmann, K.D.; Wende, K.; Bogaerts, A.; Bekeschus, S. Ros from physical plasmas: Redox chemistry for biomedical therapy. Oxid. Med. Cell. Longev. 2019, 2019, 9062098. [CrossRef]

5. Bekeschus, S.; Schmidt, A.; Weltmann, K.-D.; von Woedtke, T. The plasma jet kinpen-A powerful tool for wound healing. Clin. Plas. Med. 2016, 4, 19-28. [CrossRef]

6. Conway, G.E.; He, Z.; Hutanu, A.L.; Cribaro, G.P.; Manaloto, E.; Casey, A.; Traynor, D.; Milosavljevic, V.; Howe, O.; Barcia, C.; et al. Cold atmospheric plasma induces accumulation of lysosomes and caspase-independent cell death in u373mg glioblastoma multiforme cells. Sci. Rep. 2019, 9, 12891. [CrossRef]

7. Privat-Maldonado, A.; Gorbanev, Y.; Dewilde, S.; Smits, E.; Bogaerts, A. Reduction of human glioblastoma spheroids using cold atmospheric plasma: The combined effect of short- and long-lived reactive species. Cancers 2018, 10, 394. [CrossRef]

8. Siu, A.; Volotskova, O.; Cheng, X.; Khalsa, S.S.; Bian, K.; Murad, F.; Keidar, M.; Sherman, J.H. Differential effects of cold atmospheric plasma in the treatment of malignant glioma. PLoS ONE 2015, 10, e0126313. [CrossRef]

9. Tanaka, H.; Mizuno, M.; Katsumata, Y.; Ishikawa, K.; Kondo, H.; Hashizume, H.; Okazaki, Y.; Toyokuni, S.; Nakamura, K.; Yoshikawa, N.; et al. Oxidative stress-dependent and -independent death of glioblastoma cells induced by non-thermal plasma-exposed solutions. Sci. Rep. 2019, 9, 13657. [CrossRef]

10. Chen, Z.; Simonyan, H.; Cheng, X.; Gjika, E.; Lin, L.; Canady, J.; Sherman, J.H.; Young, C.; Keidar, M. A novel micro cold atmospheric plasma device for glioblastoma both in vitro and in vivo. Cancers 2017, 9, 61. [CrossRef]

11. Soni, V.; Adhikari, M.; Simonyan, H.; Lin, L.; Sherman, J.H.; Young, C.N.; Keidar, M. In vitro and in vivo enhancement of temozolomide effect in human glioblastoma by non-invasive application of cold atmospheric plasma. Cancers 2021, 13, 4485 . [CrossRef] [PubMed]

12. Vandamme, M.; Robert, E.; Lerondel, S.; Sarron, V.; Ries, D.; Dozias, S.; Sobilo, J.; Gosset, D.; Kieda, C.; Legrain, B.; et al. Ros implication in a new antitumor strategy based on non-thermal plasma. Int. J. Cancer 2012, 130, 2185-2194. [CrossRef]

13. Daeschlein, G.; Hillmann, A.; Gumbel, D.; Sicher, C.; von Podewils, S.; Stope, M.B.; Junger, M. Enhanced anticancer efficacy by drug chemotherapy and cold atmospheric plasma against melanoma and glioblastoma cell lines in vitro. IEEE Trans. Radiat. Plasma Med Sci. 2018, 2, 153-159. [CrossRef]

14. Gjika, E.; Pal-Ghosh, S.; Kirschner, M.E.; Lin, L.; Sherman, J.H.; Stepp, M.A.; Keidar, M. Combination therapy of cold atmospheric plasma (cap) with temozolomide in the treatment of u87mg glioblastoma cells. Sci. Rep. 2020, 10, 16495. [CrossRef] [PubMed]

15. Manaloto, E.; Gowen, A.A.; Lesniak, A.; He, Z.; Casey, A.; Cullen, P.J.; Curtin, J.F. Cold atmospheric plasma induces silver nanoparticle uptake, oxidative dissolution and enhanced cytotoxicity in glioblastoma multiforme cells. Arch. Biochem. Biophys. 2020, 689, 108462. [CrossRef]

16. Ali, S.; Borin, T.F.; Piranlioglu, R.; Ara, R.; Lebedyeva, I.; Angara, K.; Achyut, B.R.; Arbab, A.S.; Rashid, M.H. Changes in the tumor microenvironment and outcome for tme-targeting therapy in glioblastoma: A pilot study. PLoS ONE 2021, 16, e0246646. [CrossRef] [PubMed]

17. Apetoh, L.; Ghiringhelli, F.; Tesniere, A.; Criollo, A.; Ortiz, C.; Lidereau, R.; Mariette, C.; Chaput, N.; Mira, J.P.; Delaloge, S.; et al. The interaction between hmgb1 and tlr4 dictates the outcome of anticancer chemotherapy and radiotherapy. Immunol. Rev. 2007, 220, 47-59. [CrossRef]

18. Bald, T.; Landsberg, J.; Lopez-Ramos, D.; Renn, M.; Glodde, N.; Jansen, P.; Gaffal, E.; Steitz, J.; Tolba, R.; Kalinke, U.; et al. Immune cell-poor melanomas benefit from pd-1 blockade after targeted type i ifn activation. Cancer Discov. 2014, 4, 674-687. [CrossRef]

19. Balermpas, P.; Rodel, F.; Liberz, R.; Oppermann, J.; Wagenblast, J.; Ghanaati, S.; Harter, P.N.; Mittelbronn, M.; Weiss, C.; Rodel, C.; et al. Head and neck cancer relapse after chemoradiotherapy correlates with cd163+ macrophages in primary tumour and cd11b+ myeloid cells in recurrences. Br. J. Cancer 2014, 111, 1509-1518. [CrossRef]

20. Canning, M.; Guo, G.; Yu, M.; Myint, C.; Groves, M.W.; Byrd, J.K.; Cui, Y. Heterogeneity of the head and neck squamous cell carcinoma immune landscape and its impact on immunotherapy. Front. Cell Dev. Biol. 2019, 7, 52. [CrossRef] 
21. Lisi, L.; Ciotti, G.M.; Braun, D.; Kalinin, S.; Curro, D.; Dello Russo, C.; Coli, A.; Mangiola, A.; Anile, C.; Feinstein, D.L.; et al. Expression of inos, cd163 and arg-1 taken as $\mathrm{m} 1$ and $\mathrm{m} 2$ markers of microglial polarization in human glioblastoma and the surrounding normal parenchyma. Neurosci. Lett. 2017, 645, 106-112. [CrossRef]

22. Hasanpour Segherlou, Z.; Nouri-Vaskeh, M.; Noroozi Guilandehi, S.; Baghbanzadeh, A.; Zand, R.; Baradaran, B.; Zarei, M. Gdf-15: Diagnostic, prognostic, and therapeutic significance in glioblastoma multiforme. J. Cell. Physiol. 2021, 236, 5564-5581. [CrossRef]

23. Bekeschus, S.; Masur, K.; Kolata, J.; Wende, K.; Schmidt, A.; Bundscherer, L.; Barton, A.; Kramer, A.; Bröker, B.; Weltmann, K.-D. Human mononuclear cell survival and proliferation is modulated by cold atmospheric plasma jet. Plasma Process. Polym. 2013, 10, 706-713. [CrossRef]

24. Reuter, S.; von Woedtke, T.; Weltmann, K.D. The kinpen-A review on physics and chemistry of the atmospheric pressure plasma jet and its applications. J. Phys. D Appl. Phys. 2018, 51, 233001. [CrossRef]

25. Bekeschus, S.; Schmidt, A.; Niessner, F.; Gerling, T.; Weltmann, K.D.; Wende, K. Basic research in plasma medicine-A throughput approach from liquids to cells. J. Vis. Exp. 2017, e56331. [CrossRef] [PubMed]

26. Hansch, M.A.C.; Mann, M.; Weltmann, K.D.; von Woedtke, T. Analysis of antibacterial efficacy of plasma-treated sodium chloride solutions. J. Phys. D Appl. Phys. 2015, 48, 454001. [CrossRef]

27. Bekeschus, S.; Kolata, J.; Winterbourn, C.; Kramer, A.; Turner, R.; Weltmann, K.D.; Broker, B.; Masur, K. Hydrogen peroxide: A central player in physical plasma-induced oxidative stress in human blood cells. Free Radic. Res. 2014, 48, 542-549. [CrossRef] [PubMed]

28. Adhikari, M.; Adhikari, B.; Adhikari, A.; Yan, D.; Soni, V.; Sherman, J.; Keidar, M. Cold atmospheric plasma as a novel therapeutic tool for the treatment of brain cancer. Curr. Pharm. Des. 2020, 26, 2195-2206. [CrossRef]

29. Krakstad, C.; Chekenya, M. Survival signalling and apoptosis resistance in glioblastomas: Opportunities for targeted therapeutics. Mol. Cancer 2010, 9, 135. [CrossRef]

30. Strik, H.; Deininger, M.; Streffer, J.; Grote, E.; Wickboldt, J.; Dichgans, J.; Weller, M.; Meyermann, R. Bcl-2 family protein expression in initial and recurrent glioblastomas: Modulation by radiochemotherapy. J. Neurol. Neurosurg. Psychiatry 1999, 67, 763-768. [CrossRef]

31. Ishaq, M.; Kumar, S.; Varinli, H.; Han, Z.J.; Rider, A.E.; Evans, M.D.; Murphy, A.B.; Ostrikov, K. Atmospheric gas plasma-induced ros production activates tnf-ask1 pathway for the induction of melanoma cancer cell apoptosis. Mol. Biol. Cell 2014, 25, 1523-1531. [CrossRef]

32. Bekeschus, S.; Moritz, J.; Helfrich, I.; Boeckmann, L.; Weltmann, K.-D.; Emmert, S.; Metelmann, H.-R.; Stoffels, I.; von Woedtke, T. Ex vivo exposure of human melanoma tissue to cold physical plasma elicits apoptosis and modulates inflammation. Appl. Sci. 2020, 10, 1971. [CrossRef]

33. Saadati, F.; Moritz, J.; Berner, J.; Freund, E.; Miebach, L.; Helfrich, I.; Stoffels, I.; Emmert, S.; Bekeschus, S. Patient-derived human basal and cutaneous squamous cell carcinoma tissues display apoptosis and immunomodulation following gas plasma exposure with a certified argon jet. Int. J. Mol. Sci. 2021, 22, 11446. [CrossRef]

34. Akbari, Z.; Saadati, F.; Mahdikia, H.; Freund, E.; Abbasvandi, F.; Shokri, B.; Zali, H.; Bekeschus, S. Antitumor effects in gas plasma-treated patient-derived microtissues-An adjuvant therapy for ulcerating breast cancer? Appl. Sci. 2021, 11, 4527. [CrossRef]

35. Metelmann, H.-R.; Seebauer, C.; Miller, V.; Fridman, A.; Bauer, G.; Graves, D.B.; Pouvesle, J.-M.; Rutkowski, R.; Schuster, M.; Bekeschus, S.; et al. Clinical experience with cold plasma in the treatment of locally advanced head and neck cancer. Clin. Plas. Med. 2018, 9, 6-13. [CrossRef]

36. Akter, M.; Jangra, A.; Choi, S.A.; Choi, E.H.; Han, I. Non-thermal atmospheric pressure bio-compatible plasma stimulates apoptosis via p38/mapk mechanism in u87 malignant glioblastoma. Cancers 2020, 12, 245. [CrossRef]

37. Noch, E.K.; Ramakrishna, R.; Magge, R. Challenges in the treatment of glioblastoma: Multisystem mechanisms of therapeutic resistance. World Neurosurg. 2018, 116, 505-517. [CrossRef]

38. Osuka, S.; Van Meir, E.G. Overcoming therapeutic resistance in glioblastoma: The way forward. J. Clin. Investig. 2017, 127, 415-426. [CrossRef]

39. Goswami, S.; Gupta, A.; Sharma, S.K. Interleukin-6-mediated autocrine growth promotion in human glioblastoma multiforme cell line u87mg. J. Neurochem. 1998, 71, 1837-1845. [CrossRef]

40. Tchirkov, A.; Rolhion, C.; Bertrand, S.; Dore, J.F.; Dubost, J.J.; Verrelle, P. Il-6 gene amplification and expression in human glioblastomas. Br. J. Cancer 2001, 85, 518-522. [CrossRef] [PubMed]

41. Borsellino, N.; Belldegrun, A.; Bonavida, B. Endogenous interleukin-6 is a resistance factor for cis-diamminedichloroplatinum and etoposide-mediated cytotoxicity of human prostate carcinoma cell-lines. Cancer Res. 1995, 55, 4633-4639. [PubMed]

42. Wang, Q.; He, Z.; Huang, M.; Liu, T.; Wang, Y.; Xu, H.; Duan, H.; Ma, P.; Zhang, L.; Zamvil, S.S.; et al. Vascular niche il-6 induces alternative macrophage activation in glioblastoma through hif-2alpha. Nat. Commun. 2018, 9, 559. [CrossRef] [PubMed]

43. Kore, R.A.; Abraham, E.C. Inflammatory cytokines, interleukin-1 beta and tumor necrosis factor-alpha, upregulated in glioblastoma multiforme, raise the levels of cryab in exosomes secreted by u373 glioma cells. Biochem. Biophys. Res. Commun. 2014, 453 , 326-331. [CrossRef]

44. Schwamborn, J.; Lindecke, A.; Elvers, M.; Horejschi, V.; Kerick, M.; Rafigh, M.; Pfeiffer, J.; Prullage, M.; Kaltschmidt, B.; Kaltschmidt, C. Microarray analysis of tumor necrosis factor alpha induced gene expression in u373 human glioblastoma cells. BMC Genom. 2003, 4, 46. [CrossRef] 
45. Lailler, C.; Louandre, C.; Morisse, M.C.; Lhossein, T.; Godin, C.; Lottin, M.; Constans, J.M.; Chauffert, B.; Galmiche, A.; Saidak, Z. Erk1/2 signaling regulates the immune microenvironment and macrophage recruitment in glioblastoma. Biosci. Rep. 2019, 39, BSR20191433. [CrossRef]

46. Achyut, B.R.; Angara, K.; Jain, M.; Borin, T.F.; Rashid, M.H.; Iskander, A.S.M.; Ara, R.; Kolhe, R.; Howard, S.; Venugopal, N.; et al. Canonical nfkappab signaling in myeloid cells is required for the glioblastoma growth. Sci. Rep. 2017, 7, 13754. [CrossRef] [PubMed]

47. Warta, R.; Herold-Mende, C. Helping egfr inhibition to block cancer. Nat. Neurosci. 2017, 20, 1035-1037. [CrossRef] [PubMed]

48. Guo, G.; Gong, K.; Ali, S.; Ali, N.; Shallwani, S.; Hatanpaa, K.J.; Pan, E.; Mickey, B.; Burma, S.; Wang, D.H. A tnf-jnk-axl-erk signaling axis mediates primary resistance to egfr inhibition in glioblastoma. Nat. Neurosci. 2017, 20, 1074-1084. [CrossRef]

49. Guo, G.; Gong, K.; Puliyappadamba, V.T.; Panchani, N.; Pan, E.; Mukherjee, B.; Damanwalla, Z.; Bharia, S.; Hatanpaa, K.J.; Gerber, D.E. Efficacy of egfr plus tnf inhibition in a preclinical model of temozolomide-resistant glioblastoma. Neuro-Oncology 2019, 21, 1529-1539. [CrossRef]

50. Vera, C.; Tapia, V.; Vega, M.; Romero, C. Role of nerve growth factor and its trka receptor in normal ovarian and epithelial ovarian cancer angiogenesis. J. Ovarian Res. 2014, 7, 82. [CrossRef]

51. Gentry, J.J.; Barker, P.A.; Carter, B.D. The p75 neurotrophin receptor: Multiple interactors and numerous functions. Prog. Brain Res. 2004, 146, 25-39. [CrossRef]

52. Park, J.C.; Chang, I.B.; Ahn, J.H.; Kim, J.H.; Song, J.H.; Moon, S.M.; Park, Y.H. Nerve growth factor stimulates glioblastoma proliferation through notch1 receptor signaling. J. Korean Neurosurg. Soc. 2018, 61, 441-449. [CrossRef]

53. Lu, Y.; Jiang, F.; Zheng, X.; Katakowski, M.; Buller, B.; To, S.S.; Chopp, M. Tgf-beta1 promotes motility and invasiveness of glioma cells through activation of adam17. Oncol. Rep. 2011, 25, 1329-1335. [CrossRef]

54. Wang, X.Q.; Tao, B.B.; Li, B.; Wang, X.H.; Zhang, W.C.; Wan, L.; Hua, X.M.; Li, S.T. Overexpression of trem2 enhances glioma cell proliferation and invasion: A therapeutic target in human glioma. Oncotarget 2016, 7, 2354-2366. [CrossRef]

55. Ye, X.Z.; Xu, S.L.; Xin, Y.H.; Yu, S.C.; Ping, Y.F.; Chen, L.; Xiao, H.L.; Wang, B.; Yi, L.; Wang, Q.L.; et al. Tumor-associated microglia/macrophages enhance the invasion of glioma stem-like cells via tgf-beta1 signaling pathway. J. Immunol. 2012, 189, 444-453. [CrossRef] [PubMed]

56. Markovic, D.S.; Glass, R.; Synowitz, M.; Rooijen, N.; Kettenmann, H. Microglia stimulate the invasiveness of glioma cells by increasing the activity of metalloprotease-2. J. Neuropathol. Exp. Neurol. 2005, 64, 754-762. [CrossRef]

57. Schiffer, D.; Annovazzi, L.; Casalone, C.; Corona, C.; Mellai, M. Glioblastoma: Microenvironment and niche concept. Cancers 2018, 11, 5. [CrossRef]

58. Charles, N.A.; Holland, E.C.; Gilbertson, R.; Glass, R.; Kettenmann, H. The brain tumor microenvironment. Glia 2012, 60, 502-514. [CrossRef] [PubMed]

59. Cheng, X.Q.; Sherman, J.; Murphy, W.; Ratovitski, E.; Canady, J.; Keidar, M. The effect of tuning cold plasma composition on glioblastoma cell viability. PLoS ONE 2014, 9, e98652. [CrossRef] [PubMed]

60. Yan, D.; Wang, Q.; Malyavko, A.; Zolotukhin, D.B.; Adhikari, M.; Sherman, J.H.; Keidar, M. The anti-glioblastoma effect of cold atmospheric plasma treatment: Physical pathway v.s. Chemical pathway. Sci. Rep. 2020, 10, 11788. [CrossRef]

61. Akter, M.; Lim, J.S.; Choi, E.H.; Han, I. Non-thermal biocompatible plasma jet induction of apoptosis in brain cancer cells. Cells 2021, 10, 236. [CrossRef]

62. Wende, K.; Reuter, S.; von Woedtke, T.; Weltmann, K.D.; Masur, K. Redox-based assay for assessment of biological impact of plasma treatment. Plasma Process. Polym. 2014, 11, 655-663. [CrossRef]

63. Buechler, C.; Ritter, M.; Orsó, E.; Langmann, T.; Klucken, J.; Schmitz, G. Regulation of scavenger receptor cd163 expression in human monocytes and macrophages by pro- and antiinflammatory stimuli. J. Leukoc. Biol. 2000, 67, 97-103. [CrossRef]

64. Benner, B.; Scarberry, L.; Suarez-Kelly, L.P.; Duggan, M.C.; Campbell, A.R.; Smith, E.; Lapurga, G.; Jiang, K.; Butchar, J.P.; Tridandapani, S.; et al. Generation of monocyte-derived tumor-associated macrophages using tumor-conditioned media provides a novel method to study tumor-associated macrophages in vitro. J. Immunother. Cancer 2019, 7, 140. [CrossRef]

65. Chavez-Galan, L.; Olleros, M.L.; Vesin, D.; Garcia, I. Much more than $\mathrm{m} 1$ and $\mathrm{m} 2 \mathrm{macrophages,} \mathrm{there} \mathrm{are} \mathrm{also} \mathrm{cd169(+)} \mathrm{and} \mathrm{tcr(+)}$ macrophages. Front. Immunol. 2015, 6, 263. [CrossRef]

66. Affandi, A.J.; Olesek, K.; Grabowska, J.; Nijen Twilhaar, M.K.; Rodriguez, E.; Saris, A.; Zwart, E.S.; Nossent, E.J.; Kalay, H.; de Kok, M.; et al. Cd169 defines activated cd14(+) monocytes with enhanced cd8(+) t cell activation capacity. Front. Immunol. 2021, 12, 697840. [CrossRef] [PubMed]

67. Bedin, A.S.; Makinson, A.; Picot, M.C.; Mennechet, F.; Malergue, F.; Pisoni, A.; Nyiramigisha, E.; Montagnier, L.; Bollore, K.; Debiesse, S.; et al. Monocyte cd169 expression as a biomarker in the early diagnosis of coronavirus disease 2019. J. Infect. Dis. 2021, 223, 562-567. [CrossRef]

68. Sharma, I.; Singh, A.; Siraj, F.; Saxena, S. Il-8/cxcr1/2 signalling promotes tumor cell proliferation, invasion and vascular mimicry in glioblastoma. J. Biomed. Sci. 2018, 25, 62. [CrossRef]

69. Zhu, V.F.; Yang, J.; Lebrun, D.G.; Li, M. Understanding the role of cytokines in glioblastoma multiforme pathogenesis. Cancer Lett. 2012, 316, 139-150. [CrossRef] [PubMed]

70. Bekeschus, S.; Schmidt, A.; Bethge, L.; Masur, K.; von Woedtke, T.; Hasse, S.; Wende, K. Redox stimulation of human thp-1 monocytes in response to cold physical plasma. Oxid. Med. Cell. Longev. 2016, 2016, 5910695. [CrossRef]

71. Sies, H. Oxidative stress: A concept in redox biology and medicine. Redox Biol. 2015, 4, 180-183. [CrossRef] 
72. Dokic, I.; Hartmann, C.; Herold-Mende, C.; Regnier-Vigouroux, A. Glutathione peroxidase 1 activity dictates the sensitivity of glioblastoma cells to oxidative stress. Glia 2012, 60, 1785-1800. [CrossRef]

73. Toler, S.M.; Noe, D.; Sharma, A. Selective enhancement of cellular oxidative stress by chloroquine: Implications for the treatment of glioblastoma multiforme. Neurosurg. Focus 2006, 21, E10. [CrossRef] [PubMed]

74. Cheng, X.; Geng, F.; Pan, M.; Wu, X.; Zhong, Y.; Wang, C.; Tian, Z.; Cheng, C.; Zhang, R.; Puduvalli, V. Targeting dgat1 ameliorates glioblastoma by increasing fat catabolism and oxidative stress. Cell Metab. 2020, 32, 229.e8-242.e8. [CrossRef] [PubMed]

75. Xiao, A.Y.; Maynard, M.R.; Piett, C.G.; Nagel, Z.D.; Alexander, J.S.; Kevil, C.G.; Berridge, M.V.; Pattillo, C.B.; Rosen, L.R.; Miriyala, S.; et al. Sodium sulfide selectively induces oxidative stress, DNA damage, and mitochondrial dysfunction and radiosensitizes glioblastoma (gbm) cells. Redox Biol. 2019, 26, 101220. [CrossRef]

76. Pasqual-Melo, G.; Sagwal, S.K.; Freund, E.; Gandhirajan, R.K.; Frey, B.; von Woedtke, T.; Gaipl, U.; Bekeschus, S. Combination of gas plasma and radiotherapy has immunostimulatory potential and additive toxicity in murine melanoma cells in vitro. Int. $J$. Mol. Sci. 2020, 21, 1379. [CrossRef]

77. Lafontaine, J.; Boisvert, J.-S.; Glory, A.; Coulombe, S.; Wong, P. Synergy between non-thermal plasma with radiation therapy and olaparib in a panel of breast cancer cell lines. Cancers 2020, 12,348. [CrossRef]

78. Southwell, D.G.; Birk, H.S.; Han, S.J.; Li, J.; Sall, J.W.; Berger, M.S. Resection of gliomas deemed inoperable by neurosurgeons based on preoperative imaging studies. J. Neurosurg. 2018, 129, 567-575. [CrossRef] [PubMed]

79. Carson, B.S., Sr.; Wu, Q.; Tyler, B.; Sukay, L.; Raychaudhuri, R.; DiMeco, F.; Clatterbuck, R.E.; Olivi, A.; Guarnieri, M. New approach to tumor therapy for inoperable areas of the brain: Chronic intraparenchymal drug delivery. J. Neuro-Oncol. 2002, 60, 151-158. [CrossRef] 